Траченко Л. А., auditor.kandidat@ukr.net,ORCID ID:0000-0002-5505-1345, Researcher ID: B-4175-2015,

д.е.н., дои., доцент кафедри економіки, права та управління бізнесом, Одеський національний економічний університет, м. Одеса

Доброва Н. В., dobrova1623@ukr.net, ORCID ID: 0000-0002-1786-1291, к. е. н., дои., доцент кафедри економіки, права та управління бізнесом, Одеський національний економічний університет, м. Одеса

\title{
ПРОЦЕСНИЙ ПІДХІД У ФОРМУВАННІ ПРОГРАМИ ОПЕРАЦІЙНОӤ ДІЯЛЬНОСТІ ПІДПРИЕМСТВ
}

\begin{abstract}
Анотація. У статті доведено, щуо процесний підхід є основою сучасного інструментарію прийняття управлінських рішень на підприємствах різних сфер діяльності. Обгрунтовано, щуо використання процесного підходу в формуванні виробничої програми підприємства визначається тим, що його розробка потребує визначення чіткої послідовності окремих етапів, процедур і планових розрахунків. Розглянуто застосування системного підходу щзодо розробки комплексно обтрунтованої виробничої програми підприємства. Наголочено на доичільності застосування традиційного, ичільового та оптимального методів реалізації процесного підходу щчодо формування виробничої програми підприємства і розкрито сутність кожного з них. Проаналізовано склад $i$ послідовність основних етапів проиесу формування виробничої програми підприємства з визначенням методів їх реалізації. Запропоновано програму операційної діяльності для підприємств сфери інжсиірингових послуг $з$ урахуванням вимог міжнародного стандарту ISO 9001:2015 щцодо формування систем управління якістю. Доведено, ш⿻о суттєвим доповненням до складу основних етапів програми операчійної діяльності підприємств сфери інжинірингових послуг є експертне оцінювання бізнес-процесів і формування та впровадження коригувальних дій, які реалізуються за допомогою иільового методу. Запропоновано логіко-структурну схему експертного очінювання бізнес-процесів як засобу реалізації важливого етапу формування виробничої програми підприємств сфери інжинірингових послуг та поліпшення їх систем управління якістю. У результаті проведених досліджень зроблено висновок, щзо запровадження логіко-структурної схеми експертного оцінювання бізнеспроиесів дозволить підприємствам своєчасно виявляти проблеми формування програми операційної діяльності, приймати управлінські рішення щзодо усунення причин їх виникнення та забезпечувати більш ефективну реалізацію процесного підходу в їхніх системах управління якістю.
\end{abstract}

Ключові слова: процесний підхід, програма операційної діяльності, методи, стандарт ISO 9001:2015, системи управління якістю, експертне оцінювання бізнес-процесів.

Trachenko L. A.,

auditor.kandidat@ukr.net, ORCIDID:0000-0002-5505-1345,

Researcher ID: B-4175-2015,

Doctor of Economics, Associate Professor, Associate Professor of the Department of Economics, Law and Business Management, Odesa National University of Economics, Odesa

Dobrova N. V., dobrova1623@ukr.net, ORCID ID:0000-0002-1786-1291,

Ph.D., Associate Professor, Associate Professor of the Department of Economics, Law and Business Management, Odesa National University of Economics, Odesa

\section{PROCESS APPROACH IN FORMATION OF THE PROGRAM OF ENTERPRISES OPERATIONAL ACTIVITY}

\footnotetext{
Abstract. The article proves that the process approach is the basis of modern tools for making management decisions at enterprises in various fields. It is substantiated that the use of the process approach in the formation of the production program of the enterprise is determined by the fact that its development requires the definition of a clear sequence of individual stages, procedures and planned calculations. The application of a systematic approach to the development of a comprehensive production program of the enterprise is considered. Emphasis is placed on the
} 


\section{Herald of Lviv University of Trade and Economics. Economic Sciences. № 64, 2021}

feasibility of using traditional, targeted and optimal methods of implementing a process approach to the formation of the production program of the enterprise and revealed the essence of each of them. The composition and sequence of the main stages of the process of forming the production program of the enterprise with the definition of methods of their implementation are analyzed. The program of operational activity for the enterprises of the sphere of engineering services taking into account requirements of the international standard ISO 9001: 2015 concerning formation of quality management systems is proposed. It is proved that a significant addition to the main stages of the program of operational activities of enterprises in the field of engineering services is the expert assessment of business processes and the formation and implementation of corrective actions, which are implemented using the target method. The logical-structural scheme of expert assessment of business processes as a tool for implementation of an important stage of formation of the production program of engineering services enterprises as well as improvement of their quality management systems is proposed. As a result of the research it was concluded that the introduction of logical-structural scheme of expert evaluation of business processes will allow companies to identify problems of operational activities programs, make management decisions to eliminate their causes and ensure more effective implementation of the process approach in their quality management systems.

Key words: process approach, operational program, methods, ISO 9001: 2015 standard, quality management systems, expert evaluation of business processes.

$$
\begin{aligned}
& \text { JEL Classification: L15, L21, L84, M2 } \\
& \text { DOI: https://doi.org/10.36477/2522-1205-2021-64-13 }
\end{aligned}
$$

Постановка проблеми. У нинішніх умовах бурхливого розвитку науково-технічного прогресу, глобалізації і жорсткої конкуренції процесний підхід став основою сучасного інструментарію прийняття управлінських рішень на підприємствах різних сфер діяльності. Переваги процесного підходу $\epsilon$ очевидними, оскільки саме він є дієвим інструментом поліпшення управління та забезпечення ключових цілей діяльності підприємств. Посилено акцент на застосуванні процесного підходу в системах управління якістю (СУЯ) підприємств, оскільки це $\epsilon$ важливим аспектом у забезпеченні успішного бізнесу. Разом з тим, проблемою ефективного застосування процесного підходу є відсутність обгрунтованих методів його реалізації та формування етапів процесу формування виробничої програми підприємства.

Аналіз останніх досліджень і публікацій. Процесний підхід досліджували такі вчені, як К. С. Безгін, І. В. Гришина, М. Ф. Зяйлик, А. Г. Киселев, І. О. Кузнецова, Ю. А. Сгупов та інші. Вони акцентували увагу на трактуванні сутності процесного підходу, питаннях щодо бізнес-процесів. Безгін К. С. обгрунтував необхідність впровадження й використання процесного підходу як найбільш відповідного сучасним вимогам до якості процесу створення споживчої цінності. Сгупов Ю. А. досліджував розвиток підходів при формуванні виробничої програми підприємства. Кузнецова I. О. розглядала процесний підхід до управління та розвитку виробництва.

Незважаючи на суттєві дослідження, надано недостатньо уваги методичним аспектам щодо застосування процесного підходу в формуванні програми операційної діяльності підприємств.

Постановка завдання. Метою статті є визначення основних етапів формування виробничої програми підприємства та методів їх реалізації на основі процесного підходу.
Виклад основного матеріалу дослідження. Діяльність підприємств повинна здійснюватись із застосуванням процесного підходу. Сучасна парадигма управління, а також високий динамізм змін, що відбуваються у зовнішньому середовищі, передбачає перехід від системно-диференційованої (функціональної) до системно-інтегрованої (процесної) структури управління. Основною метою впровадження й використання процесноорієнтованого підходу до управління $є$ зниження вартості кінцевого результату і підвищення його споживчої цінності для максимального задоволення споживачів, що в умовах трансформаційного періоду української економіки стає системоутворюючим фактором [1]. Перевагою процесного підходу $\epsilon$ наступне: представляючи процес виробництва продукції або послуги у вигляді послідовності операцій, ми краще розуміємо структуру формування цінності для споживача. Представляючи структуру формування цінності, ми уявлясмо також і структуру виникнення втрат якості. Знаючи “хворі місця", ми можемо запобігати втраті якості, замість того, щоб витрачати сили і кошти на відновлення вже втраченої цінності [2].

Головна відмінна риса процесного підходу полягає в тому, що спрямований він не на управління діяльністю функціональних підрозділів, а на виконання бізнес-процесів, під якими розуміються сукупності послідовних дій із перетворення отриманих на вході ресурсів у кінцевий продукт, що має цінність для споживача, на виході [3]. На сьогоднішній день процесний підхід став невід'ємною частиною, стрижневою основою сучасного інструментарію вирішення широкого спектра управлінських завдань [4].

Заслуговує на увагу дослідження I. О. Кузнецової [5], в основу якого покладено визначення основних параметрів моделі, що реалізує процесний підхід до управління, які включають: входи, виходи; склад, послідовність і раціональні методи 
виконання операцій процесу управління. Стосовно планування виробництва це буде означати, що для побудови інформаційної моделі процесу формування виробничої програми (ПФВП) необхідно визначити:

- цілі ПФВП;

- склад етапів ПФВП;

- послідовність етапів ПФВП;

- склад і функціональне призначення інструментарію, що використовується на кожному етапі ПФВП [5].

На думку Ю. А. Сгупова [6], необхідність використання процесного підходу до формування виробничої програми (ВП) підприємства визначається тим, що його розробку слід розглядати насамперед як процес, що включає строгу послідовність окремих етапів, процедур і планових розрахунків. На основі функціонального підходу здійснюється чіткий розподіл функціональних обов'язків між окремими учасниками зазначеного процесу.

Застосування системного підходу забезпечує розробку комплексно обгрунтованої ВП. 3 цією метою на підприємствах формується цілісна система комплексного обгрунтування ВП (СКОВП), яка $\epsilon$ складовою частиною системи тактичного планування. СКОВП включає низку підсистем, у межах яких здійснюються окремі процеси формування ВП. Зокрема, підсистеми маркетингового, ресурсного, інноваційно-інвестиційного й аналітичного обгрунтування ВП [7].

Відповідно до авторської позиції Ю. А. Сгупова підхід до планування ВП визначається сукупністю окремих процесів та інструментів, що відрізняються цільовою установкою, складом етапів (процесів), їхньою послідовністю, специфікою й функціональним призначенням інструментарію, що використовується. До методів реалізації процесного підходу щодо формування ВП віднесено традиційний, цільовий та оптимальний. Автор наголошує на застосуванні декількох методів реалізації процесного підходу для вирішення зазначеного завдання.

Традиційний метод полягає у формуванні комплексно обгрунтованої ВП, тобто такого плану виробництва, який був би обгрунтований споживчим попитом на продукцію, що випускається, з одного боку, i наявними виробничими ресурсами підприємства, з іншого.

Ринкові відносини продиктували необхідність упровадження цільового методу, мета якого полягає в забезпеченні досягнення цільових показників операційної діяльності підприємства (цільового чистого операційного прибутку, цільового рівня надійності операційної діяльності підприємства).

Метою оптимізаційного методу реалізації процесного підходу $\epsilon$ формування оптимальної ВП (ОВП), тобто такого збалансованого за попитом i ресурсами плану виробництва, який забезпечує досягнення екстремального значення критеріального показника. Застосовують такі критерії оптимальності, як максимальний обсяг виробництва, максимальна сума прибутку від реалізації продукції, мінімальні простої технологічного устаткування або максимальна ринкова частка підприємства. Крім цільової установки, найважливішими відмінностями розглянутих методів є склад і послідовність основних етапів процесу формування ВП (табл. 1) [6].

Очевидно, що цільовий метод порівняно з традиційним містить три додаткові етапи. Останні пов'язані 3 обгрунтуванням номенклатури й значень цільових показників діяльності підприємства, а також забезпеченням їхнього досягнення. Оптимізаційний метод включає такі специфічні етапи, як побудова економіко-математичної моделі, здійснення оптимізаційних розрахунків та аналіз отриманих результатів.

Склад основних етапів формування виробничої програми підприсмства

Таблиия 1

\begin{tabular}{|c|c|c|c|}
\hline \multirow[t]{2}{*}{ Етапи процесу формування ВП } & \multicolumn{3}{|c|}{$\begin{array}{c}\text { Методи реалізації процесного підходу щодо } \\
\text { формування ВП підприємства }\end{array}$} \\
\hline & традиційний & цільовий & оптимізаційний \\
\hline Маркетингові дослідження & + & + & + \\
\hline Обгрунтування складу й рівня цільових показників & - & + & - \\
\hline Розробка планових балансів виробничих ресурсів & + & + & - \\
\hline Економічна оцінка ВП & - & + & - \\
\hline $\begin{array}{l}\text { Коригування параметрів тактичного плану за резуль- } \\
\text { татами економічної оцінки ВП }\end{array}$ & - & + & - \\
\hline $\begin{array}{l}\text { Побудова економіко-математичної моделі ОВП і } \\
\text { здійснення оптимізаційних розрахунків }\end{array}$ & - & - & + \\
\hline Аналіз результатів оптимізаційних розрахунків & - & - & + \\
\hline
\end{tabular}

Джерело: [6] 
У результаті здійснення оптимізаційних розрахунків буде сформована ВП, основною якісною характеристикою якої $\epsilon$ не ії оптимальність, а комплексна обгрунтованість останньої як за всіма видами споживаних ресурсів, так і за попитом на окремі найменування продукції.

Далі за результатами економічної оцінки ВП ухвалюється рішення про їі затвердження або про необхідність коригування низки параметрів в окремих підсистемах СКОВП підприємства.

На нашу думку, такий науковий підхід автора [7] до процесного підходу заслуговує на увагу та доцільний до застосування на виробничих підприємствах. Разом з тим, проведений аналіз дозволив дійти висновку, що його можна розглядати як важливий інструмент щодо управління якістю на підприємствах сфери інжинірингових послуг при запровадженні певних доповнень та змін.

Зважаючи на вимоги п. 8.1 стандарту ISO 9001:2015 щодо формування систем управління якістю (СУя) [8], для операційного планування та управління нами запропонована програма операційної діяльності (ПОД) підприємств сфери інжинірингових послуг (із застосуванням методів реалізації процесного підходу) (табл. 2).

Враховуючи специфіку діяльності підприємств сфери інжинірингових послуг, вважаємо суттєвим доповнення складу основних етапів програми операційної діяльності підприємств ще двома - експертне оцінювання бізнес-процесів із застосуванням простих статистичних методів і формування та впровадження коригувальних дій за результатами експертного оцінювання, що реалізуються за допомогою цільового методу. Разом з тим, пропонуємо доповнити методи реалізації процесного підходу ще одним - комбінований, який містить традиційний, цільовий і оптимізаційний та є більш ефективним для застосування на підприємствах сфери інжинірингових послуг.

Таблиия 2

Структура формування програми операційної діяльності підприсмств сфери інжинірингових послуг (із застосуванням методів реалізації процесного підходу)

\begin{tabular}{|c|c|c|c|c|}
\hline \multirow{2}{*}{$\begin{array}{c}\text { Етапи процесу формування програми опе- } \\
\text { раційної діяльності }\end{array}$} & \multicolumn{4}{|c|}{$\begin{array}{c}\text { Методи реалізації процесного підходу до формування } \\
\text { ПОД }\end{array}$} \\
\hline & $\begin{array}{l}\text { традицій- } \\
\text { ний }\end{array}$ & цільовий & $\begin{array}{l}\text { оптиміза- } \\
\text { ційний }\end{array}$ & $\begin{array}{l}\text { комбі- } \\
\text { нований }\end{array}$ \\
\hline Маркетингові дослідження & + & + & + & + \\
\hline $\begin{array}{l}\text { Обгрунтування вимог до виконання робіт } \\
\text { (послуг) }\end{array}$ & - & + & - & + \\
\hline $\begin{array}{l}\text { Визначення ресурсів для виконання робіт } \\
\text { (послуг) }\end{array}$ & + & + & - & + \\
\hline $\begin{array}{l}\text { Економічна оцінка ПОД на основі аналізу } \\
\text { витрат на виконання робіт (послуг) }\end{array}$ & - & + & - & + \\
\hline $\begin{array}{l}\text { Коригування тактичного плану за результа- } \\
\text { тами економічної оцінки ПОД }\end{array}$ & - & + & - & + \\
\hline $\begin{array}{l}\text { Побудова економіко-математичної моделі } \\
\text { оптимізації організації виконання робіт і } \\
\text { здійснення відповідних розрахунків }\end{array}$ & - & - & + & + \\
\hline $\begin{array}{l}\text { Аналіз результатів оптимізаційних розра- } \\
\text { хунків та формування оптимальної сукуп- } \\
\text { ності виконання робіт }\end{array}$ & - & - & + & + \\
\hline $\begin{array}{l}\text { Експертне оцінювання виконання робіт із } \\
\text { застосуванням комплексу статистичних } \\
\text { методів }\end{array}$ & + & + & - & + \\
\hline $\begin{array}{l}\text { Формування та впровадження коригуваль- } \\
\text { них дій за результатами експертного оці- } \\
\text { нювання }\end{array}$ & + & + & - & + \\
\hline
\end{tabular}

Джерело: складено на основі [5] 
Доцільно акцентувати увагу на розробці логікоструктурної схеми експертного оцінювання бізнеспроцесів і із застосуванням комплексу статистичних методів (рис. 1) [9].

Такий підхід дає змогу виявляти проблеми щодо функціонування бізнес-процесів, а отже, процесів СУЯ та встановлювати причинно-наслідковий ланцюг для постійного поліпшення результативності й посилення ефективності їх функціонування та доцільний для застосування на всіх етапах життєвого циклу виконання робіт (послуг) у сфері інжинірингу [10].

Для ефективного застосування розробленої логіко-структурної схеми експертного оцінювання процесів СУЯ й бізнес-процесів підприємствам сфери інжинірингових послуг доцільно створити відділ управління якістю як головний орган щодо з'ясування проблем якості бізнес-процесів та функціонування й поліпшення процесів СУЯ.

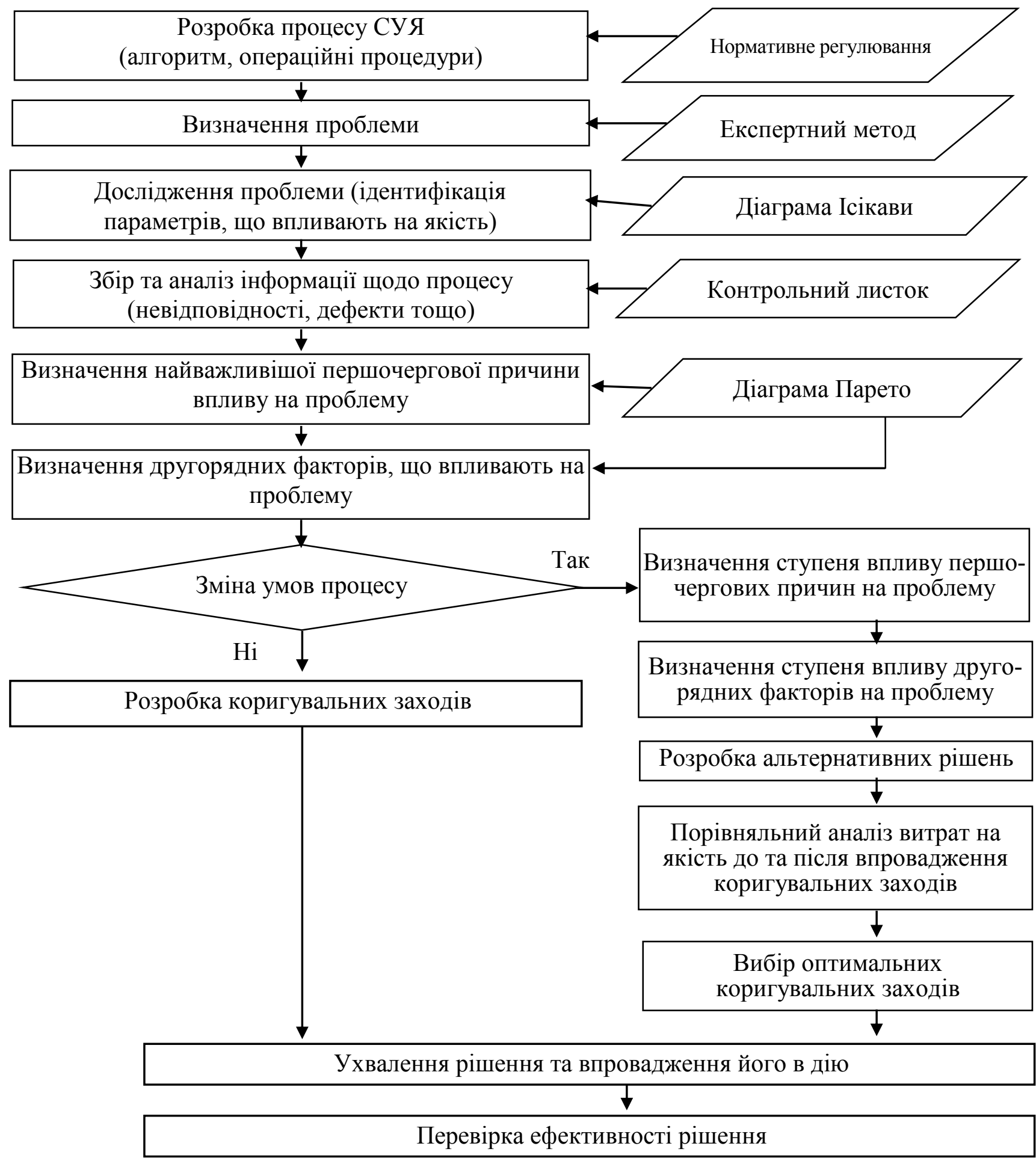

Рис. 1. Логіко-структурна схема експертного оцінювання бізнес-процесів підприємств сфери інжинірингових послуг (розроблено автором) 


\section{Herald of Lviv University of Trade and Economics. Economic Sciences. № 64, 2021}

Вище керівництво підприємства має ініціювати такі організаційні зміни насамперед для забезпечення важливого статусу діяльності щодо СУЯ.

Висновки і перспективи подальших досліджень у даному напрямі. У результаті проведених досліджень зроблено висновок, що запровадження логіко-структурної схеми експертного оцінювання бізнес-процесів дозволить підприємствам своєчасно виявляти проблеми формування програми операційної діяльності, приймати управлінські рішення щодо усунення причин їх виникнення та забезпечувати більш ефективну реалізацію процесного підходу в їхніх СУЯ.

\section{ЛІТЕРАТУРА}

1. Безгін К. С. Порівняльний аналіз процесного та функціонального підходів до управління підприємством / Безгін К. С., Гришина I. В. // Вісник економічної науки України. - 2009. - № 2 (16). C. 3-7.

2. Зяйлик М. Ф. Процесний підхід до менеджменту якості / Зяйлик М. Ф., Вівчар О. І. // Інноваційна економіка. - 2013. - №1. - С. 191-194.

3. Киселев А. Г. Бизнес-процессы и процессный подход: как преодолеть последствия консалтингового маркетинга [Електронний ресурс]. Режим доступу: http://orgstructura.ru/businessprocesses-andprocess-approach.

4. Бизнес-процессы - основа эффективного управления предприятием [Електронний ресурс]. Режим доступу: https://www.u-b-s.ru/publikacii/ biznes-processy.html.

5. Кузнецова I. О. Моніторинг як складова процесу управління підприємством хлібопродуктів: теорія та методологія : монографія / Кузнецова I. О. - Одеса : “Друкарський дім”, 2009. - 228 с.

6. Сгупов Ю. А. Розвиток підходів до формування виробничої програми підприємства / Єгупов Ю. А. // Інноваційна економіка. - 2016. № 3-4. - С. 50-56.

7. Сгупов Ю. А. Системний підхід до планування ресурсного забезпечення виробничої програми підприємства / Єгупов Ю. А. // Актуальні проблеми економіки. - 2013. - № 10. - С. 126-137.

8. ДСТУ ISO 9000:2015 (ISO 9000:2015, IDT). Системи управління якістю. Основні положення та словник термінів. [Чинний від 2016-07-01]. Вид. офіц. - К. : ДП “УкрНДНЦ”, 2016. - 45 с.

9. Траченко Л. А. Системи управління якістю підприємств сфери інжинірингу : монографія / Траченко Л. А. - Одеса : ОНЕУ, 2019. - 380 с.
10. Траченко Л. А. Алгоритм експертного оцінювання процесів систем управління якістю на підприємствах сфери інжинірингових послуг : proceedings of the 6 th International scientific and practical conference - Eurasian scientific congress (Barcelona, June 14-16, 2020). - Barcelona, Spain : Barca Academy Publishing, 2020. - P. 578-585.

\section{REFERENCES}

1. Bezghin, K. S. and Hryshyna, I. V. (2009), Porivnial'nyj analiz protsesnoho ta funktsional'noho pidkhodiv do upravlinnia pidpryiemstvom, Visnyk ekonomichnoi nauky Ukrainy, № 2 (16), s. 3-7.

2. Ziajlyk, M. F. and Vivchar, O. I. (2013), Protsesnyj pidkhid do menedzhmentu iakosti, Innovatsijna ekonomika, №1, c. 191-194.

3. Kyselev, A. H. Byznes-protsessy y protsessnyj podkhod: kak preodolet' posledstvyia konsaltynhovoho marketynha, available at: http://orgstructura.ru/ business-processes-andprocess-approach.

4. Byznes-protsessy - osnova effektyvnoho upravlenyia predpryiatyem, available at: https://www.u-b-s.ru/publikacii/biznes-processy.html.

5. Kuznetsova, I. O. (2009), Monitorynh iak skladova protsesu upravlinnia pidpryiemstvom khliboproduktiv: teoriia ta metodolohiia : monohrafiia, "Drukars'kyj dim", Odesa, 228 s.

6. Yehupov, Yu. A. (2016), Rozvytok pidkhodiv do formuvannia vyrobnychoi prohramy pidpryiemstva, Innovatsijna ekonomika, № 3-4, s. 50-56.

7. Yehupov, Yu. A. (2013), Systemnyj pidkhid do planuvannia resursnoho zabezpechennia vyrobnychoi prohramy pidpryiemstva, Aktual'ni problemy ekonomiky, № 10, s. 126-137.

8. DSTU ISO 9000:2015 (ISO 9000:2015, IDT). Systemy upravlinnia iakistiu. Osnovni polozhennia ta slovnyk terminiv. [Chynnyj vid 2016-07-01]. Vyd. ofits. (2016), DP "UkrNDNTs", K., 45 s.

9. Trachenko, L. A. (2019), Systemy upravlinnia iakistiu pidpryiemstv sfery inzhynirynhu : monohrafiia, ONEU, Odesa, $380 \mathrm{~s}$.

10. Trachenko, L. A. (2020), Alhorytm ekspertnoho otsiniuvannia protsesiv system upravlinnia iakistiu na pidpryiemstvakh sfery inzhynirynhovykh posluh : proceedings of the 6 th International scientific and practical conference - Eurasian scientific congress (Barcelona, June 14-16, 2020), Barca Academy Publishing, Barcelona, Spain, r. 578-585.

Стаття надійшла до редакиії 4 липня 2021 року 